\title{
THE EFFECT OF FREEZE-THAW CYCLES ON THE GEOTECHNICAL PROPERTIES OF CLAYEY SOIL TREATED WITH LIME
}

\author{
NiHAD BaHAaldeEn SALIH ${ }^{1}$ and TAVGa ARAm ABDalla \\ College of Engineering, University of Sulaimani, Kurdistan Region-Iraq
}

(Accepted for Publication: December 8, 2020)

\begin{abstract}
Fine-grained soils (cohesive soils) exposed to freezing-thawing cycles exhibit to notable alterations on their physical and mechanical characteristics. The environmental conditions' influences on soil geotechnical properties are significant, especially when stabilized by hydrated lime. This study was carried out to explore the effect of freeze-thaw cycles on cohesive soil stabilized by various hydrated lime percentages (zero\%, $5 \%, 10 \%$, and $15 \%$ ) by dry mass, which cured for 28 days at $30^{\circ} \mathrm{C}$. One-dimensional consolidations, unconfined strength, and shear box tests were performed for untreated and treated soil samples subjected to $0,1,2$, and 3 freeze-thaw cycles. Duplication of freeze-thaw cycles significantly impacts some geotechnical properties and decreases them such as LL, UCS, Cc, Cr, and C. The PL and $\phi$ values of the samples treated by hydrated lime and subjected to freeze-thaw cycles observed to be increased, which were due to the important role of hydrated lime addition. It is concluded that the hydrated lime can be effectively utilized to minimize the impacts of freeze-thaw periods on shear strength and compressibility of cohesive soil.
\end{abstract}

Keywords: Cohesive soils, Hydrated Lime, Freeze-Thaw cycles, Durability

\section{INTRODUCTION}

$\mathbf{I}$ n cool districts, the frost motion and the associated frost heave is seriously impacting on fine-grain soils properties. This type of heave is due to the volume change of water, in the soil pores, during the freezing process. Generally, when the water is fully frozen its volume among the soil particles is increased by $9 \%$ and hence leads to heave and thus cracks occurrence (Xian et al., 2019). These changes impact many construction projects for instance highways, railways, pipeline, and structures construction. In addition, in cold regions also, soils mechanical characteristics significantly influenced due to frost lenses formed among soil grains throughout freeze in addition to water surplus through the melting period (Konrad, 1989). Freezing-thawing process affect soils strength, permeability and compressibility (Esna-Ashari and Jafari, 2012; Wang et. al., 2009; Li et al., 2012).

In some studies, soil consistency can be changed because of the freezing and thawing process (Yong et al., 1985; Viklander \& Eigenbrod, 2000). While in other studies soil consistency was not changed significantly due to the freezing and thawing process (Yong et al., 1985; Eigenbrod, 1996). Hence, freeze-thaw cycles can alter some geotechnical properties (strength, permeability, and compressibility) severely (Hohmann-Porebska, 2002; Qi et al., 2006). Researchers were more emphasis on shear strength properties than soil modulus of elasticity. Soil modulus results were affected by freeze-thaw cycles, which showed firstly a decrease, then an increase with freeze-thaw cycles (Wang et al., 2007; Liu et al., 2016). Coefficient of consolidation $\left(\mathrm{C}_{\mathrm{v}}\right)$ considered in few researches, $C_{v}$ values reported in the literature of fine grained soils from permafrost regions were summarized in the study of Paudel and Wang (2009) and showed that the coefficient of consolidation was increased after freezing and thawing cycles.

Stabilized soils might behave in different ways during freeze-thaw cycles. The addition of lime to the clayey soil was improved its mechanical characteristics (Al-Kiki et al., 2011); however, the untreated soil was not capable to afford the effects of the environmental cases. In addition, comparable behaviors were reported in the study of Aldaood et al. (2014). The further stresses produced by seasonal temperature tavga.abdalla@univsul.edu.iq 
changes also found to be resisted by the stabilized soil, especially during freeze-thaw cycles (Guney et al., 2006). Using of lime found to be useful, which discovered to be affecting on the engineering characteristics of soils. The role of lime in improving of the soil engineering characteristics such as strength and durability was mentioned in the studies of Bell (1993), AlRawas et al. (2005), and Guney et al. (2007). Moreover, limited studies have been conducted to study the durability of treated clay soil subjected to Freeze-Thaw cycles (Al-Mukhtar et al., 2012; Locat et al., 1996).

Other stabilization resources, fly ash, furthermore studied in the same regard. It was found that the F-Th cycles to be insignificant to improve plasticity property of treated soils by fly ash (Bin-Shafique et al., 2010). These impacts can substantially decrease the bearing capacity of foundation materials and their shearing resistance (Aldaood et al., 2014; Kamei et al., 2012; Wang et al., 2007). The main aim of current research is to examine the influence of hydrated lime content on the physical and mechanical behaviors of a cohesive soil exposed to three F-Th cycles.

\section{MATERIAL AND MAETHODOLOGY \\ 2.1 Materials}

Barika soil selected in the current research, which is located in Sulaimani city, Kurdistan Region of Iraq has Latitude $35^{\circ} 33^{\prime} 40^{\prime \prime} \mathrm{N}$ and Longitude of $45^{\circ} 26^{\prime} 14^{\prime \prime}$. The sample collected from $1.0 \mathrm{~m}$ to $2.0 \mathrm{~m}$ underneath the earth's surface. It is a light brown color, and it can be categorized as CL soil considering the Unified Soil Classification System (USCS) (Rashed et al., 2017; Salih, 2020). The grain size distribution curve of the soil sample and its engineering properties are shown in Fig. 1 and Table 1 respectively. For the purpose of soil treatment, locally-available manufactured hydrated lime was selected. Table 2 shows several physical properties and chemical composition of the used hydrated lime, which is a commercially available and typically use for construction purposes. The selected hydrated lime percentages for treating the cohesive soil of the current study are $0 \%, 5 \%, 10 \%$ and $15 \%$. These percentages are taken with respect to the dry mass of the soil. Geotechnical laboratory experiments were conducted according to ASTM standards as follows: ASTM D4318 (2000) as utilized to obtain the soils Atterberg limits ASTM D4318 (2000), the soils specific gravity $\left(\mathrm{G}_{\mathrm{s}}\right)$ was carried out according to ASTM D854 (2000).

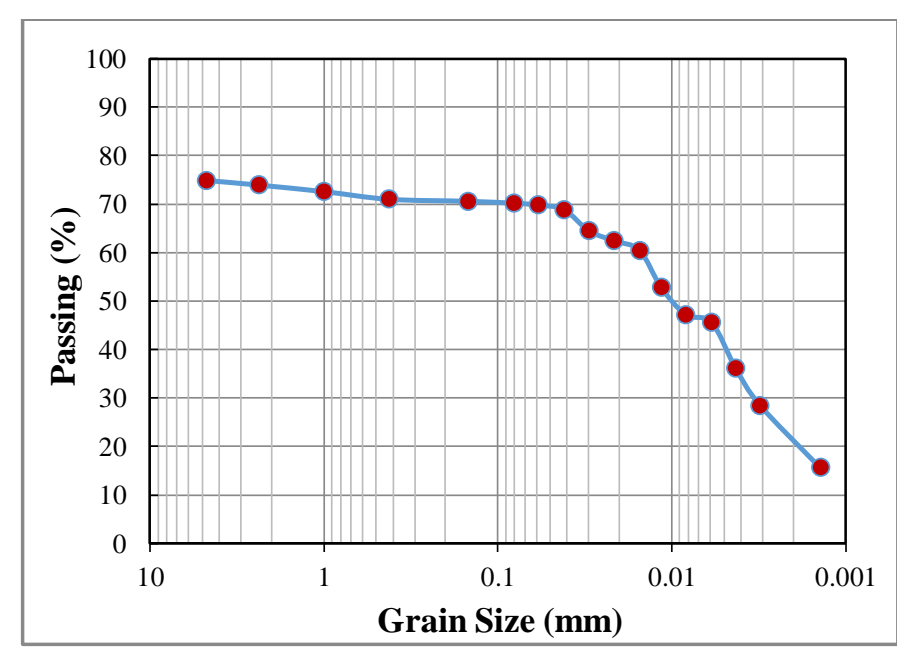

Fig. (1): Particle size chart for the investigated Barika Soil.

nihad.salih@univsul.edu.iq; tavga.abdalla@univsul.edu.iq

${ }^{1}$ Corresponding author: College of Engineering, University of Sulaimani, Kurdistan Region, Iraq 
Table (1): Basic physical parameters for the tested soil (Barika soil).

\begin{tabular}{cc}
\hline Property & Value \\
\hline Natural moisture content (\%) & 18.7 \\
\hline Color & Light Brown \\
\hline LL (\%) & 44.6 \\
\hline LP (\%) & 19.5 \\
\hline PI (\%) & 25.2 \\
\hline Specify gravity & 2.67 \\
\hline MDD (g/cm $\left.{ }^{3}\right)$ & 1.57 \\
\hline OMC (\%) & 27.25 \\
\hline Silt + Clay (\%) & 70 \\
\hline Uniaxial compressive strength $(\mathrm{KPa})$ & 174.2 \\
\hline
\end{tabular}

Table (2): Physical and chemical compositions of used hydrated lime.

\begin{tabular}{cc}
\hline Chemical Name & Chemical Composition (\%) \\
\hline $\mathrm{CaO}$ & 56.1 \\
\hline $\mathrm{MgO}$ & 0.13 \\
\hline $\mathrm{Fe} 2 \mathrm{O} 3$ & 0.12 \\
\hline $\mathrm{AlOO} 3$ & 0.72 \\
\hline $\mathrm{SiO} 2$ & 1.38 \\
\hline $\mathrm{SO} 3$ & 0.21 \\
\hline L.O.I & 40.6 \\
\hline & Physical Properties \\
\hline \% passing sieve No.200 $(0.075)$ & 98 \\
\hline Surface Area $\left(\mathrm{m}^{2} / \mathrm{kg}\right)$ & 398 \\
\hline Specific gravity & 2.78 \\
\hline
\end{tabular}

\subsection{The Study Methodology}

In the current study, natural and treated cohesive soil specimens were tested to obtain some of the soil's geotechnical properties. Hydrated-lime was used to treat the natural soil specimens and cured for 28 days. At the end of 28 days curing, the treated specimens were exposed to three F-Th cycles, based on the procedures suggested by ASTM D560. For the freezing cycles, prepared soil specimens are subjected to $-6{ }^{\circ} \mathrm{C}$ for 24 hours in a freezing apparatus. Then, the frozen specimens permitted to thaw at $30{ }^{\circ} \mathrm{C}$, which lasted in a container with $100 \%$ relative humidity for 24 hours. In order to obtain a successful penetration for weakening frost and thaw, $-6^{\circ} \mathrm{C}$ and $30^{\circ} \mathrm{C}$ for $\mathrm{F}$ $\mathrm{T}$ cycles were considered, which represent hydrated lime temperature. In the end of each of F-Th cycles, both of mass and water content for specimens were calculated.

Regarding the selected geotechnical properties to be checked, LL and PL tests were carried out for all specimens exposed to three FTh cycles. The unconfined compressive strength (UCS) was determined for the specimens that exposed to F-Th cycles according to ASTM standard (D-2166). The cylinder mold and used equipment for preparation of the remolded sample are shown in Fig. 2. After the conduction of the required F-Th cycles $(0,1,2$, and 3 cycles), soil specimens are used to perform the unconfined compression test at $0.5 \mathrm{~mm} / \mathrm{min}$ strain rate to gain the specimens' UCS.

Also, one dimensional consolidation experiments were performed for the stabilized samples with hydrated lime under 3 F-Th cycles according to ASTM D 2435- 11. Conventional one-dimensional consolidation test using oedometer device were used to measure soil specimens' compressibility, the used ring size is $50 \mathrm{~mm}$ in diameter and a thickness of $20 \mathrm{~mm}$. The specimen-ring assembly was sealed in a nylon bag to minimize wetness wastage. After the specimen placed in the odometer cell, loading stage started with an applied pressure of 25 and end at an $800 \mathrm{kN} / \mathrm{m}^{2}$, each stage was lasted for 24 hours. Then, the unloading stage was carried out; the load is decreased in stages of $800 \mathrm{kN} / \mathrm{m}^{2}-25 \mathrm{kN} / \mathrm{m}^{2}$ in sequencing also applied within durations of 24 hours for each stage of unloading. 

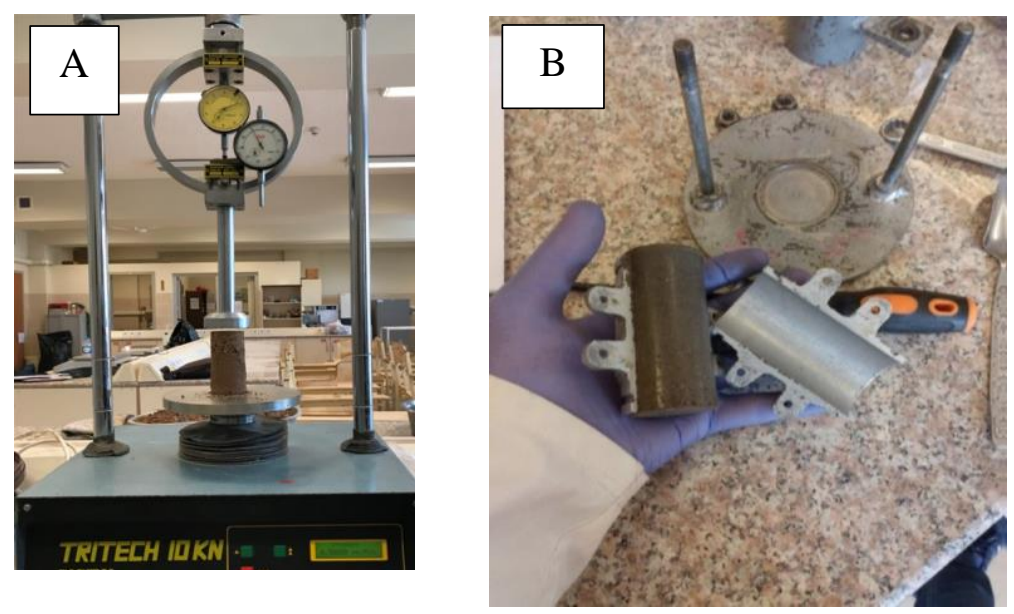

Fig. (2):: A. Unconfined compressive strength device, B. Cylindrical mold for remolded soil specimens.

Moreover, direct shear experiment was performed for the soil specimens with the various percentages of hydrated lime under $3 \mathrm{~F}$ Th cycles. Direct shear is a popular test for soils strength determination, which used for determination of the value of internal friction angle and the specimen cohesion (Head and Epps, 2011). Traditional shear box equipment was used, exposing the specimens to $27.78 \mathrm{kPa}$, $55.6 \mathrm{kPa}$ and $83.33 \mathrm{kPa}$ normal stresses by a sequence. The rate of displacement was selected to be $1.0 \mathrm{~mm} / \mathrm{min}$ for each normal stress.

\section{RESULTS AND DISCUSSION}

All the obtained results of the tested soil specimens in the natural state or the treated state by hydrated lime are compared with other available similar studies in this section. The treated specimens were left for 28 days for curing purpose. This section includes the influences of F-Th periods on the obtained variations in consistency limits (LL, PL and PI), stress-strain behaviors (UCS), compressibility parameters $\left(\mathrm{C}_{\mathrm{c}}, \mathrm{C}_{\mathrm{r}}\right.$ and $\left.\mathrm{C}_{\mathrm{v}}\right)$, and shear components $(\mathrm{C}$ and $\phi)$.

\subsection{Impact of F-Th cycles on the consistency limits of the soil}

The effect of F-Th cycles on the variation of plastic limit, liquid limit and plasticity index for untreated and treated specimens with hydrated lime is presented in Fig.3a and 3c. The presented results in the figure show that with the hydrated lime percent increase for $0,1,2$, and 3 F-Th cycles, LL \& PI decreased by a small value, but with the $3^{\text {rd }} \mathrm{F}-\mathrm{Th}$ cycle, there is a rapid increase in LL and PI values. For PL (Fig. 3b), a little change has been observed for the soil specimen subjected to all $3 \mathrm{~F}-\mathrm{Th}$ cycles. While for the soil specimen stabilized by $10 \%$ hydrated lime, a rapid reduction in the value of PL for all $3 \mathrm{~F}-\mathrm{T}$ cycles was noticed. The F-Th cycles impact on the consistency limits is noticed to be little. This result agrees with the results of some studies such as Yong et al. (1985), Eigenbrod (1996), and Zhang et al. (2019). 

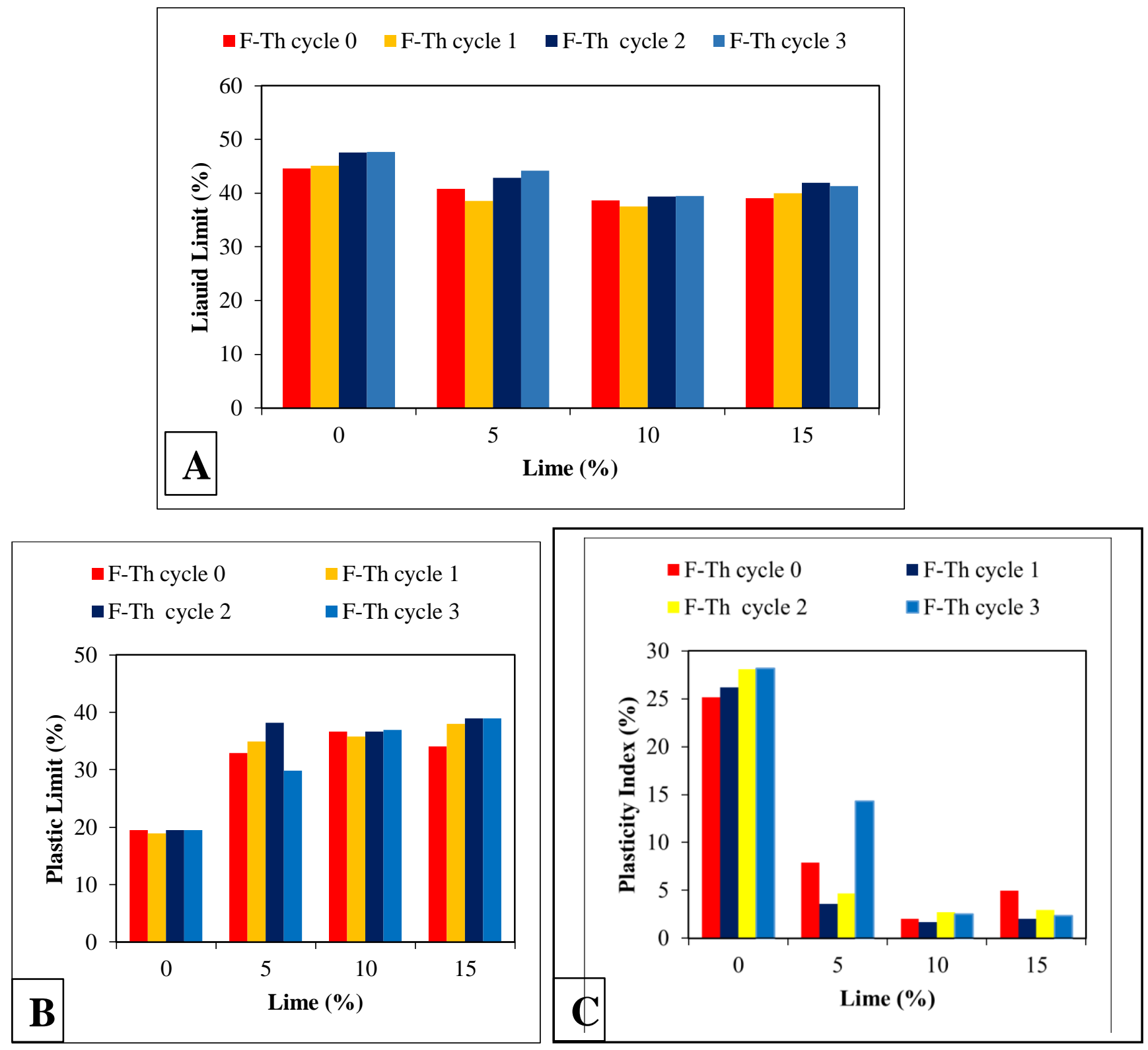

Fig. (3): Recorded changes in consistency limits of lime- stabilized soil samples with F-Th cycles: A. liquid limit; B. plastic limit, C. plasticity index.

\subsection{Effects of F-Th cycles on unconfined compressive strength}

The variation of UCS values for the treated and untreated specimens exposed to 3 F-Th cycles is presented in Fig.4. After saturation and exposing to the last cycle of F-Th process, unconfined strength tests were carried out in order to obtain the UCS. From the figure, hydrated lime noticed to has a major effect on the UCS values. The value of UCS for the untreated soil was increased due to $\mathrm{F}-\mathrm{Th}$ cycles. Therefore, and hence, the natural soil specimen outcomes showed the weakening of its properties due to $\mathrm{F}-\mathrm{T}$ cycles and it may require remediation, as it has been carried out in the current research. Also it is clear from the figure that the UCS values of the stabilized samples decreases with the F-Th cycles compared with the untreated natural soil specimen subjected to the same F-Th cycles (Konrad, 1989; Yildiz et al., 2004; Firoozi et al., 2015; Shareef, 2016). From the obtained results, the highest UCS value found to be for the $15 \%$ hydrated lime content for $0 \mathrm{~F}-\mathrm{Th}$ cycles, which is $51.1 \%$. While, for the other stabilized soil specimens after 1 to $3 \mathrm{~F}-\mathrm{Th}$ cycles, the rapid decrease in the UCS values are $19.1 \%, 26.88 \%$ and $40.91 \%$ respectively. 


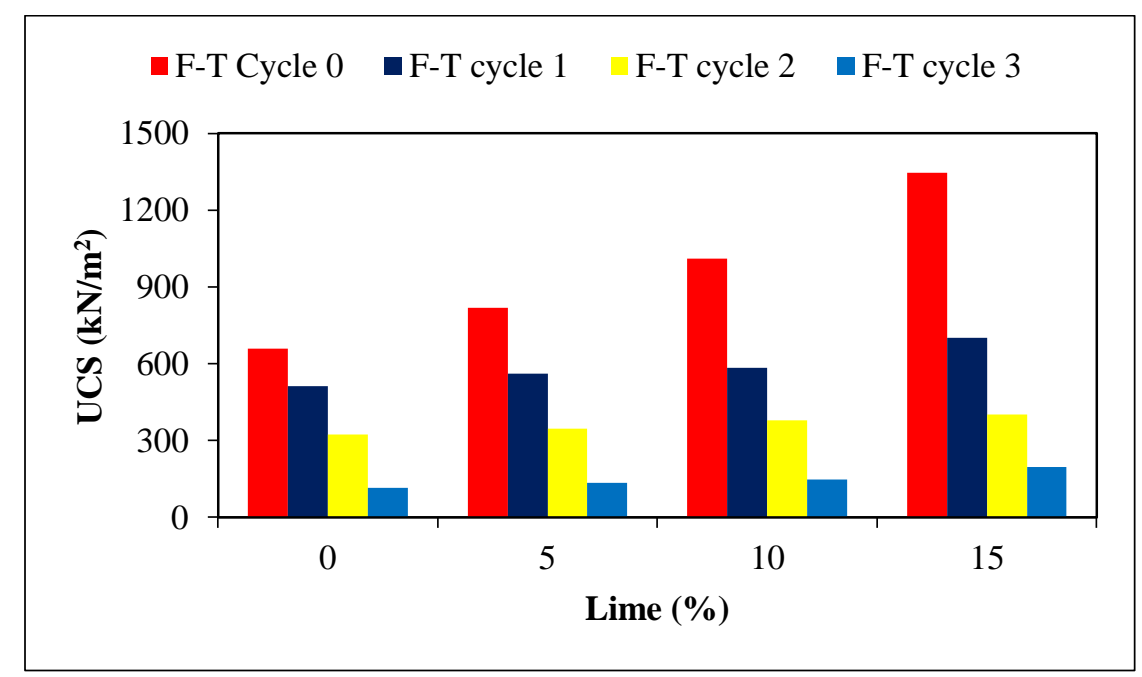

Fig. (4): Variation of UCS of lime-stabilized soil subjected to F-Th cycles.

\subsection{Impact of F-Th cycles on the shear components $(\mathbf{C} \& \phi)$}

In this research, the tested soil specimens were exposed to $3 \mathrm{~F}-\mathrm{Th}$ cycles. Rearrangement of soil particles and the curing time are two important factors to gain shear strength. The FTh cycles directly affected the specimens shear strength components. In Fig. 5, with the increase in the hydrated lime percentage from $0 \%$ to $15 \%$, the soil cohesion decreased that subjected to 0-3 F-Th cycles. Fig. 6 shows the obtained friction angle values increase that treated with hydrated lime and subjected to 3 F-Th cycles. However, a rapid decrease was noticed for the specimen that stabilized with $10 \%$ hydrated lime and exposed to 0 and $1 \mathrm{~F}-\mathrm{Th}$ cycles. After that, the trend starts to increase up to $15 \%$ of hydrated lime content. Both of shear components $(\mathrm{C}$ and $\phi)$ showed several variations with F-Th cycles increase, $\phi$ increased slightly and $\mathrm{C}$ decreased, which agree with the findings of both of Hotineanu et al. (2015) and Yao et al. (2020) studies.

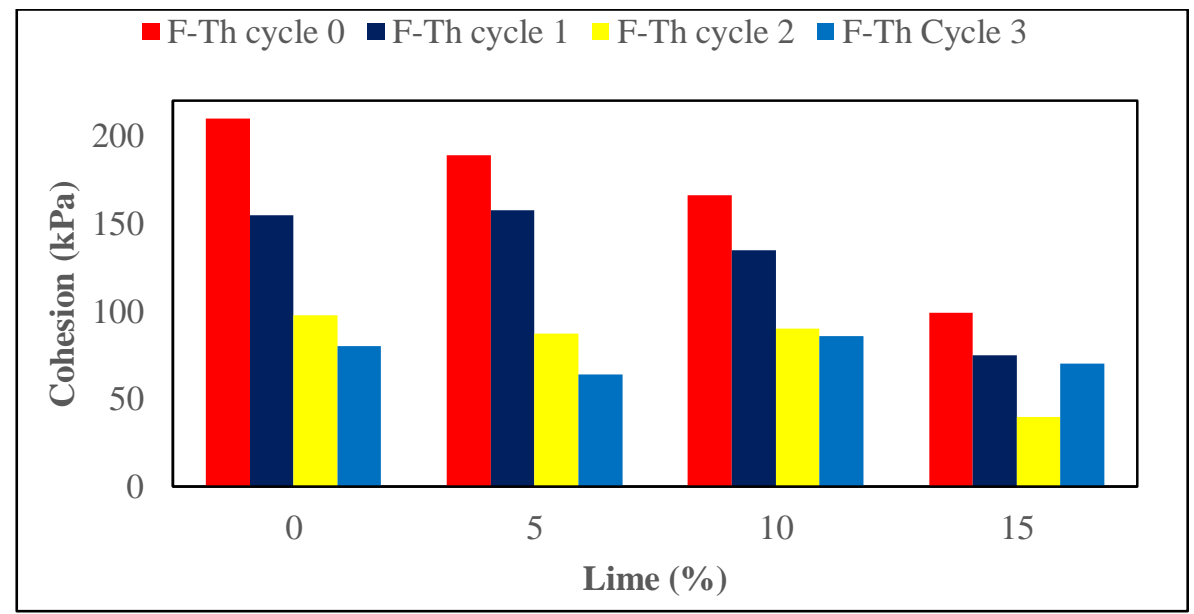

Fig. (5): Variation of cohesion of lime-stabilized soils subjected to F-Th cycles.

nihad.salih@univsul.edu.iq; tavga.abdalla@univsul.edu.iq

${ }^{1}$ Corresponding author: College of Engineering, University of Sulaimani, Kurdistan Region, Iraq 


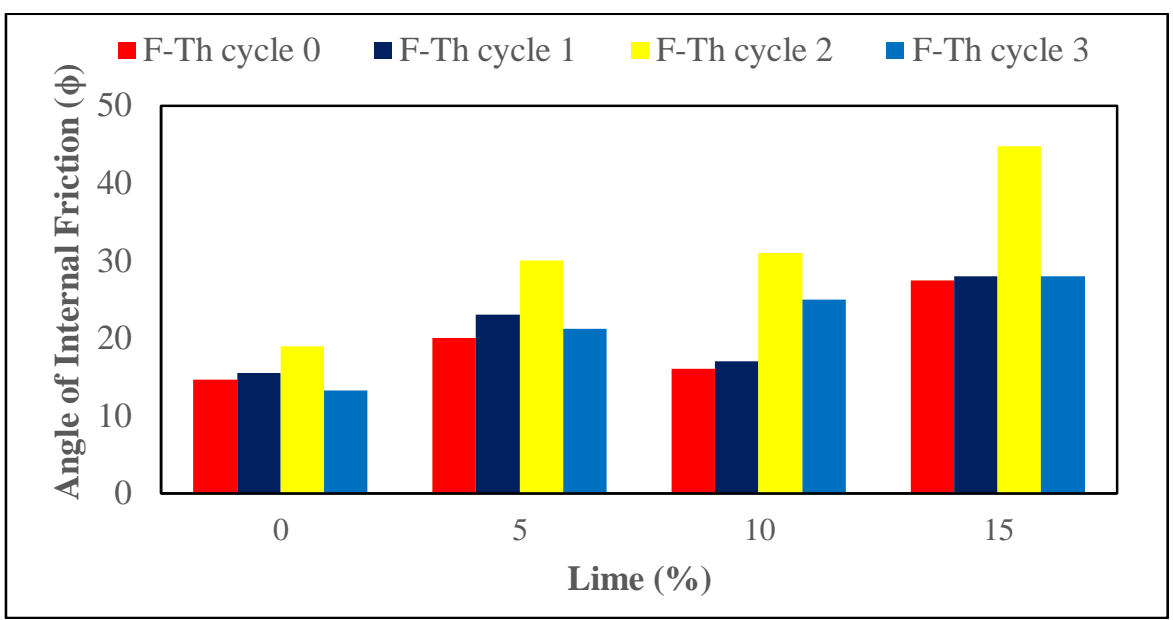

Fig. (6): Variation of angle of internal friction of lime-stabilized soil exposed to F-Th cycles.

\subsection{Impact of F-The cycles on the compressibility parameters}

One-dimensional consolidation tests were performed for both of the natural and limetreated specimens with $0 \%$ to $15 \%$ lime exposed to 3 F-Th cycles applied after treated specimens were cured for 28 Days. After that, a relationship developed between compressibility parameters with $0 \%$ and $15 \%$ hydrated lime for all $3 \mathrm{~F}-\mathrm{Th}$ cycles. As seen in Figs. 7 to 9, the compression index, expansion index, and coefficient of consolidation subjected to 0 F-T cycles with lime content of $0 \%$ have the highest values. These values decrease with the increase of the hydrated lime content. However, the increase in the first two values can be noticed at $10 \%$ then after that they started to reduce by $15 \%$. All of compressibility parameters $\left(\mathrm{C}_{\mathrm{c}}, \mathrm{C}_{\mathrm{r}}\right.$, and $\left.\mathrm{C}_{\mathrm{v}}\right)$ continued to reduce with F-Th cycles increase. Nevertheless, both of the compression and expansion indices exposed to $2 \mathrm{~F}$-Th cycles for all hydrated lime content lower than 3 F-Th cycles which presented in Figs. 7 and 8 . Coefficient of consolidation starts to decrease by order of zero to $3 \mathrm{~F}-\mathrm{Th}$ cycles for all untreated and treated specimens with hydrated lime as shown in Fig. 10; the decrease was at a much lower rate. The main reason for compressibility parameters decrease of stabilized soil by hydrated lime after exposed to $3 \mathrm{~F}-\mathrm{Th}$, cycles can enhance the formation of bonds among soil particles, which generated due to use hydrated lime (Paudel and Wang, 2009).

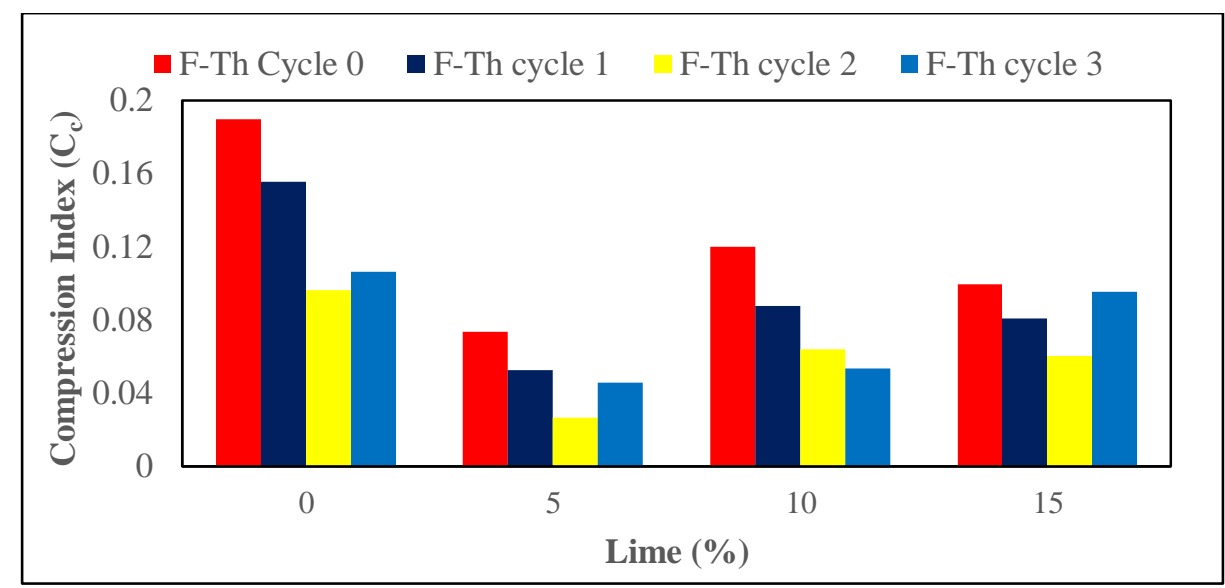

Fig. (7): Variation of compression index of lime-stabilized soil subjected to number of F-Th cycles. 


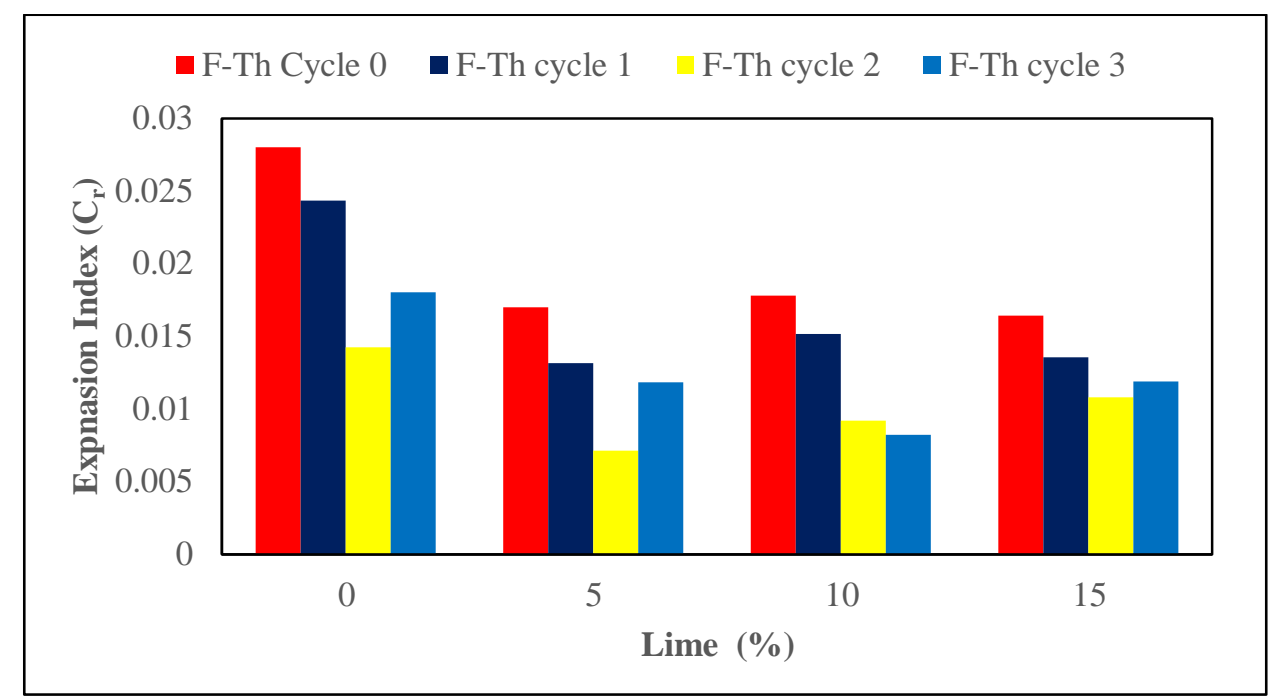

Fig. (8): Variation of expansion index of soil stabilized with lime exposed to F-Th cycles.

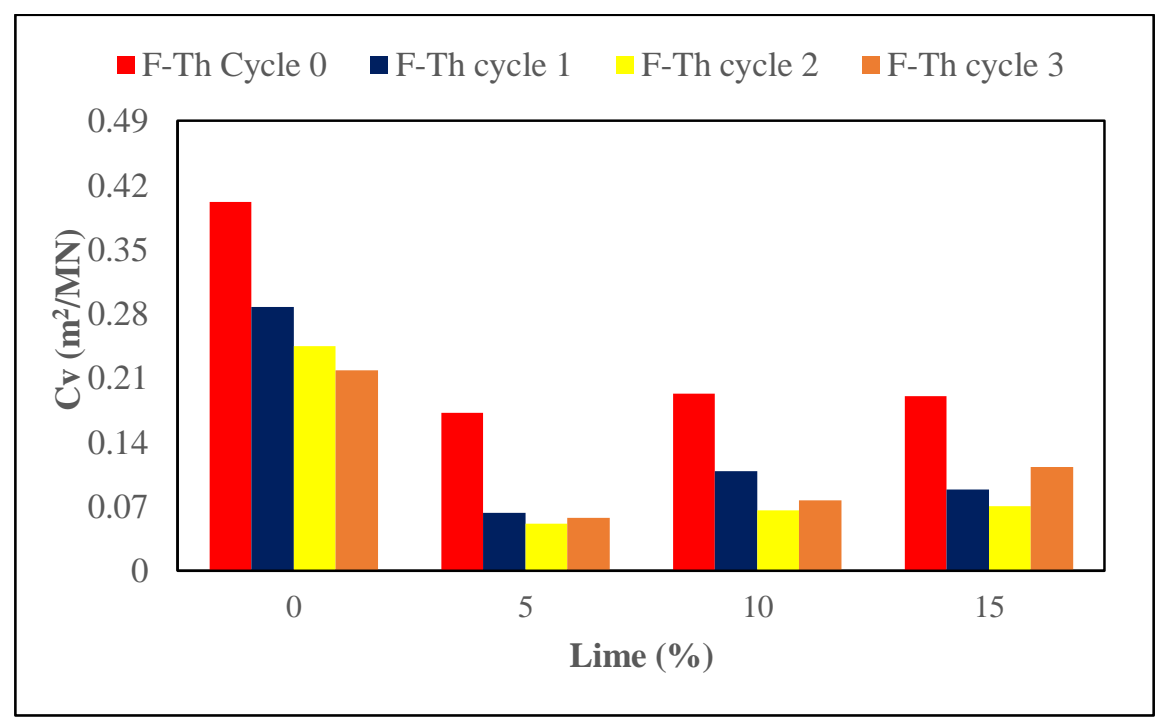

Fig. (9): Variation of coefficient of consolidation with hydrated lime percent for stabilized soil exposed to 4 cycles of F-Th.

\section{CONCLUSION}

The effect of hydrated lime on freeze-thaw cycles of fine-grained soils has been explored. Based on the obtained findings, the study yielded the following conclusions:

- Based on the F-Th cycles increase from 0 to 3 , both of LL \& PI were reduced. A remarkable increase is noticed in the values of both of LL and PI after 3 F-Th cycles.

- Based on the obtained outcomes, soil treatment by hydrated lime improved the freeze and thaw durability. The UCS of untreated and limetreated specimens reduces with F-T cycles increase.

- The cohesion of the treated soil specimens by hydrated lime reduced after the application of all
F-Th cycles. In contrast, the angle of internal friction value increased with the treatment by hydrated lime after subjecting to all F-Th cycles. - The number of F-Th cycles increase effectively influenced the compressibility characteristics of the stabilized soil specimen by hydrated-lime. Lime stabilized soils showed high resistance to compressibility compare with the non-stabilized soils. The compressibility parameters $\left(\mathrm{Cc}, \mathrm{Cr}\right.$, and $\left.\mathrm{C}_{\mathrm{v}}\right)$ decreased with $\mathrm{F}-\mathrm{Th}$ cycles. However, both of compression index and expansion index values after subjecting to $2 \mathrm{~F}$ Th cycles for all hydrated-lime contents lower than their values after subjecting to $3 \mathrm{~F}-\mathrm{Th}$ cycles.

nihad.salih@univsul.edu.iq; tavga.abdalla@univsul.edu.iq

${ }^{1}$ Corresponding author: College of Engineering, University of Sulaimani, Kurdistan Region, Iraq 


\section{List of Symbols}

\begin{tabular}{ll}
\hline \multicolumn{1}{c}{ Symbol } & \multicolumn{1}{c}{ Description } \\
\hline $\mathrm{LL}$ & Liquid Limit \\
\hline $\mathrm{PL}$ & Plastic Limit \\
\hline $\mathrm{PI}$ & Plasticity Index \\
\hline$U \mathrm{UCS}$ & Unconfined Compressive Strength \\
\hline USCS & Unified Soil Classification System \\
\hline $\mathrm{C}_{\mathrm{c}}$ & Compression Index \\
\hline $\mathrm{C}_{\mathrm{r}}$ & Expansion Index \\
\hline $\mathrm{C}_{\mathrm{v}}$ & Coefficient of Consolidation \\
\hline$\phi$ & Angle of Internal Friction \\
\hline $\mathrm{C}$ & Cohesion \\
\hline $\mathrm{F}-\mathrm{Th}$ & Freeze-Thaw \\
\hline $\mathrm{UU}$ & Unconsolidated Undrained Shear \\
\hline $\mathrm{MDD}$ & Test \\
\hline $\mathrm{OMC}$ & Maximum Dry Density \\
\hline
\end{tabular}

\section{REFERENCES}

Aldaood, A., Bouasker, M., Al-Mukhtar, M., (2014). Impact of Freeze-Thaw Cycles on Mechanical behavior of Lime Stabilized Gypseous Soils. Cold Regions Science and Technology, Vol. 99, pp. 38-45.

Al-Kiki, I., Al-Attalla, M., Al-Zubaydi, A. (2011). Long Term Strength and Durability of Clayey Soil Stabilized with Lime. Eng. \& Tech. Journal, Vol. 29 (4), pp. 725-734.

Al-Mukhtar, M., Khattab, S., Alcover, J.F., (2012). Microstructure and Geotechnical Properties of Lime-Treated Expansive Clayey Soil. Engineering Geology, 139-140, pp. 17-27.

Al-Rawas A. A., Hago A. W., and Al-Sarmi, H., (2005). Effect of Lime, Cement and Sarooj (Artificial Pozzolan) on the Swelling Potential of an Expansive Soil from Oman. Build Environ, Vol. 40, pp. 681-687.

ASTM D2166 (2006). Standard Test Method for Unconfined Compressive Strength of Cohesive Soil. American Society for Testing and Materials, Building Stones, ASTM International, Philadelphia.

ASTM D2435 (2011). Standard Test Method for One-Dimensional Consolidation Properties of Soils. American Society for Testing and Materials, Vol. 04.08, ASTM International, West Conshohocken. PA., pp. 1-10.

ASTM D4318 (2010). Standard Test Methods for Liquid Limit, Plastic Limit, and Plasticity Index of Soils, American Society for Testing and Materials, ASTM International, West Conshohocken, Pa.

ASTM D560 (2016). Standard test methods for freezing and thawing compacted soil-cement mixtures. American Society for Testing and Materials, ASTM International, West Conshohocken, PA.

Bell, F.G., (1993). Engineering Treatment of Soils. E \& FN Spon Taylor \& Francis Group, London, UK.

Bin-Shafique, S., Rahman, K., Yaykiran, M., Azfar, I., (2010). The long-Term Performance of Two Fly Ash Stabilized Fine-Grained Soil Subbases. Resources, Conservation and Recycling, Vol. 54, pp. 666-672.

Broms, B. B., and Yao, L.Y.C., (1964). Shear Strength of a Soil after Freezing and Thawing, Journal of Soil Mechanics and Foundation Div, Vol. 90 (SM4), pp. 1-25.

Eigenbrod, K. D., (1996). Effects of Cyclic Freezing and Thawing on Volume Changes and Permeability's of Soft Fine-Grained Soils. Can. Geotech. J., Vol. 33 (4), pp. 529-537.

Esna-Ashari, M., Jafari., M., (2012). Effect of Waste Tire Cord Reinforcement on Unconfined Compressive Strength of Lime Stabilized Clayey Soil Under Freeze-Thaw Condition. Cold Reg. Sci. Technol., Vol. 82, pp. 21-29.

Firoozi, A. A., Tahaa, M. R., Firoozi, A. A., and Khan, T. A., (2015). The Influence of FreezeThaw Cycles on Unconfined Compressive Strength of Clay Soils Treated with Lime. Journal Teknologi (Sciences \& Engineering), Vol. 76(1), pp. 107-113.

Hohmann-Porebska, M. (2002). Microfabric Effects in Frozen Clays in Relation to Geotechnical Parameters. Applied Clay Science, Vol. 21, pp. 77-87.

Hohmann-Porebska, M., (2002). Microfabric Effects in Frozen Clays in Relation to Geotechnical Parameters. Applied Clay Science, Vol. 21(12), pp. 77-87.

Hotineanu, A., Bouasker, M., Aldaood, A., AlMukhtar, M., (2015). Effect of Freeze-Thaw Cycling on the Mechanical Properties of Lime-Stabilized Expansive Clays. Cold Regions Science and Technology, Vol. 119, pp. 151-157.

Kamei, T., Ahmed, A., Shibi, T., (2012). Effect of Freeze-Thaw Cycles on Durability and Strength of very Soft Clay Soil Stabilized with Recycled Bassanite. Cold Regions Science and Technology, Vol. 82. pp. 124-129.

Konrad, J. M., (1989). Physical Processes during Freeze-Thaw Cycles in Clayey Silts. Cold Regions Science and Technology, Vol. 16 (3), pp. 291-303.

Konrad, J. M., (1989). Physical Processes during Freeze-Thaw Cycles in Clayey Silts. Cold 
Regions Science and Technology, 16 - 3, pp. 291-303.

Li, G., Ma, W., Zhao, S., Mao, Y. and Mu, Y. (2012). Effect of Freeze-Thaw Cycles on Mechanical Behavior of Compacted Fine-Grained Soil. ASCE Cold Regions Engineering, pp. 72-81.

Liu, J. K., D. Chang, and Yu, Q. M., (2016). Influence of Freeze-Thaw Cycles on Mechanical Properties of a Silty Sand. Eng. Geol, Vol. 210, pp. 23-32.

Locat, J., Tremblay, H., Leroueil, S., (1996). Mechanical and hydraulic behavior of a soft inorganic clay treated with lime. Canadian Geotechnical Journal, Vol. 33, pp. 654-669.

Paudel, B., and Wang, B., (2010). Coefficient of consolidation of the soils from the Mackenzie valley. GeoCal 2010 Paper, 185, pp. 992-996, URL: http://pubs.aina.ucalgary.ca/cpc/CPC6992.pdf.

Qi, J., Vermeer, P.A., Cheng, G., (2006). A Review of the Influence of Freeze-Thaw Cycles on soil Geotechnical Properties. Permafrost and Periglacial Process, Vol. 17, pp. 245-252.

Shareef A. H., (2016). Investigation of Cement with Lime as Stabilized Materials for Soft Soils. M.Sc. thesis, Building and Construction Engineering Department University of Technology, Baghdad, Iraq.

Viklander, P., Eigenbrod, D., (2000). Stone Movements and Permeability Changes in Till Caused by Freezing and Thawing. Cold Regions Science and Technology, Vol. 31, pp. 151-162.

Wang, D. y., Ma, W., Niu, Y. h., Chang, X. X., and Wen, Z., (2007). Effects of cyclic freezing and thawing on mechanical properties of QinghaiTibet clay. Cold Reg. Sci. Technol, Vol. 48 (1), pp. 34-43.

Wang, X., Yang, P., Wang, H., and Dai, H., (2009). Experimental Study on Effects of Freezing and
Thawing on Mechanical Properties of Clay. Chinese Journal of Geotechnical Engineering, Vol. 31, pp. 1768-1772.

Yao, M., Wang Q., Ma, B., Liu Y., Qingbo Yu, and Han, Y., (2020). Effect of Freeze-Thaw Cycle on Shear Strength of Lime-Solidified Dispersion Soils. Civil Engineering Journal, Vol. 6 (1), pp. 114-129.

Yildiz, M., Soganc1, A.S., Demiroz, A., Albayrak, V., (2004). The Effect of Freezing-Thawing Action on the Strength and Permeability Behavior of Lime Stabilized Clay Soil. $10^{\text {th }}$ National Congress on Soil Mechanics and Foundation Engineering, Istanbul, Turkey, pp. 227-236, (In Turkish Language).

Yong, R. N., P. Boonsinsuk, and Yin, C. W. P., (1985). Alteration of Soil Behavior after Cyclic Freezing and Thawing. Proc. $4^{\text {th }}$ Int. Symp. Ground Freezing. Singapore, pp. 187195.

Zhnag W., Guo, A., and Lin, C., (2019). Effects of Cyclic Freeze and Thaw on Engineering Properties of Compacted Loess and LimeStabilized Loess. J. Mater. Civ. Eng, Vol. 31(9), pp.1-12.

Rashed K. A., Salih N. B., and Abdalla T. A. (2017). Correlation of Consistency and Compressibility Properties of Soils in Sulaimani City. Sulaimani Journal for Engineering Sciences, Vol. 4 (5), pp. 87-95.

Salih N. B., (2020). Geotechnical characteristics correlations for fine-grained soils. IOP Conf. Ser: Master. Sci. Eng. 737012099.

Xian S., Lu Z., Yao H., Ran Fang R., and She J. (2019). Comparative Study on Mechanical Properties of Compacted Clay under FreezeThaw Cycles with Closed and Open Systems. Advances in Materials Science and Engineering, pp. 113.https://doi.org/10.1155/2019/9206372.

nihad.salih@univsul.edu.iq; tavga.abdalla@univsul.edu.iq

${ }^{1}$ Corresponding author: College of Engineering, University of Sulaimani, Kurdistan Region, Iraq 